\title{
BREAKFAST HABITS AMONG SCHOOL CHILDREN IN SELECTED COMMUNITIES IN THE EASTERN REGION OF GHANA
}

\author{
F. D. INTIFUL1 and A. LARTEY ${ }^{2}$ \\ ${ }^{1}$ University of Ghana, School of Allied Health Sciences, Department of Dietetics, P.O. Box KB 143, Korle-Bu \\ Accra, ${ }^{2}$ Department of Nutrition and Food Science, University of Ghana, P. O. Box LG 134, Legon, Accra
}

DOI: http://dx.doi.org/10.4314/gmj.v48i2.3

Corresponding Author: Dr. Freda Dzifa Intiful

Email:fdintiful@chs.edu.gh

Conflict of Interest: None declared

\section{SUMMARY}

Background: Breakfast is considered the most important meal of the day, yet many people skip breakfast. Studies indicate that school age children who regularly skip breakfast are not likely to concentrate in class, thus affecting school performance. This study determined the breakfast habits and nutrient contributions of the breakfast meal to the days' nutrient intake. Design: A cross sectional study was conducted among school children $(n=359)$ between the ages of 6-19 years in Manya Krobo in the Eastern Region of Ghana. Questionnaires were used to collect information on background characteristics and breakfast consumption habits. The 24-hour dietary recall method was used to obtain information on the children's food intake. T-test was used to compare differences between means of variables of breakfast consumers and skippers. Results: About $85.5 \%$ of the children had breakfast on the day of interview. More boys (87.8\%) consumed breakfast compared to the girls (83.1\%). For those who skipped breakfast, lack of food at home or lack of no money $(36.5 \%)$ was the main reason. Breakfast consumers had significantly higher energy and nutrient intakes than those who skipped breakfast (energy 2259 verses $1360 \mathrm{kcal}, \mathrm{p}-0.039$; vitamin A 1534 verses 662 $\mathrm{ug} / \mathrm{RE}, \mathrm{p}=0.001$; iron 22.9 verses $13.9 \mathrm{mg}, \mathrm{p}=0.017$, zinc 9.9 verses $5.6 \mathrm{mg}, \mathrm{p}=0.034$ ). The breakfast meal contributed between $32-41 \%$ of the day's energy intake, and between $30-47 \%$ of micronutrient intake. Conclusion: Encouraging breakfast consumption among school children is a way to ensure that they meet their daily nutrient and energy intakes.

Keyword: Breakfast, School children, Energy, Nutrients, Ghana

\section{INTRODUCTION}

Breakfast is the first meal of the day and is typically taken no later than mid-morning. It is frequently branded as the most important meal of the day, owing to a number of benefits including prevention of overweight, obesity and reduction in risk of cardiovascular diseas- es. ${ }^{1}$ Skipping breakfast is a common practice by people around the world. The 1999-2006 National Health and Nutrition Survey of the United States reported that between $20 \%$ and $30 \%$ of children and adolescents skipped breakfast frequently. ${ }^{2}$ In India, the proportion of children skipping breakfast regularly was even higher (over 50\%).

Breakfast is important in meeting the day's nutritional needs. Children who consume breakfast are likely to meet their energy and overall nutrient requirement compared to those who do not have breakfast. ${ }^{4,5,7,8}$ In India, children between 10 and 15 years who consumed breakfast met about one quarter to one third of their daily energy and protein intakes from the breakfast meal. ${ }^{3}$ Breakfast consumption also contributes to increase intakes of other nutrients. In a longitudinal study among girls 9-19 years, in which energy intake was adjusted for, breakfast cereal consumption was related to increased consumption of fibre, calcium, iron, folic acid, vitamin $\mathrm{C}$, and zinc, and a decrease in fat and cholesterol intake. ${ }^{9}$ Breakfast skippers in most cases are unable to compensate for the nutrients lost during the rest of the day. ${ }^{4}$

Breakfast meals contribute to improving cognition among school age children. ${ }^{10,11}$ The amount of time between the consumption of the last meal of the day and breakfast the next morning is generally longer compared to the time interval between other meals such as breakfast and lunch or lunch and dinner. ${ }^{11}$ The long-time interval results in metabolic changes that interfere with cognitive function and school performance. ${ }^{10}$ Among American children, 9-11 years old, those who took breakfast had higher mental arithmetic task performance, showed better creative thinking and improvement on performance of tasks involving processing of complex visual display. ${ }^{11,12,13}$ Other studies report improvements in tasks regarding memory function with the intake of breakfast. ${ }^{10,13,14}$ 
Studies on breakfast habits among Ghanaian children are lacking. The objective of this study was to determine the breakfast habits of Ghanaian school children and to determine the contribution of the breakfast meal to the total energy and nutrient intake for the day.

\section{METHODS}

\section{Subjects and study area}

A cross-sectional design was used for this study. Primary school children $(n=359)$ were selected from 10 public schools in the Upper and Lower Manya-Krobo Districts of the Eastern Region of Ghana. The schools were selected based on ease of access to the communities in which they are located.

The main economic activities in the district are farming, fishing and trading. In each school, children in classes one to six were eligible to participate. In each class a list of the children in the register was obtained and was stratified based on sex. Every third child on the list was selected. Permission to carry out the study in the schools was sought and obtained from the Ghana Education Service-School Health Education Program (SHEP).

Ethical clearance was obtained from the Institutional Review Board of Noguchi Memorial Institute for Medical Research of the University of Ghana, Legon. The Head of each school granted permission for the children's participation in the study. To be eligible, the child must be present on the day of interview and must be in a primary class (classes 1 to 6 ).

\section{Data Collection}

\section{Breakfast Habits}

A structured questionnaire was used to collect information on the breakfast habits of all the children. Specifically, they were asked whether they had consumed breakfast on the day of interview, the time of consumption, the number of times they consumed breakfast in the past one-week; if breakfast was skipped and the reasons for skipping was sought.

\section{Dietary Intake}

Dietary intake information was collected only on children in upper primary (class 4-6; $n=181$ ) because they can better recall foods eaten the previous day then the younger children. Using the 24 hour recall method, the children were asked to recall foods they had consumed over the past 24-hours. To aid in the recall and estimation of quantities of food eaten, household measures (such as cups, ladles, spoons,) and food models were used. The estimated quantities of food were weighed and converted into energy and nutrients using Food Composition Tables based on Ghanaian foods. ${ }^{15}$

\section{Data analysis}

Data were analysed using SPSS version 11.5. Student's $t$-tests were used to compare the mean nutrient intakes of children who consumed breakfast and those who skipped on the day of interview. Critical value for statistical significance was set at $p<0.05$.

\section{RESULTS}

The background characteristics of the children are shown on Table 1. Of the 359 children 53.2\% lived with their biological parents. The main occupation of the fathers/male guardians was farming (44.6\%). Most of the children $(95.0 \%)$ lived in the same household with their siblings.

Table 1: Background characteristics of study children $(\mathrm{N}=359$

\begin{tabular}{|l|l|}
\hline Characteristic & Number of subjects (\%) \\
\hline Age (years) & $\mathrm{N}(\%)$ \\
\hline $6-10$ & $158(44.0)$ \\
\hline $11-14$ & $181(50.4)$ \\
\hline $15-19$ & $20(5.6)$ \\
\hline Child lives with; & \\
\hline Biological Parents (both) & $191(53.2)$ \\
\hline Mother only & $55(15.3)$ \\
\hline Father only & $23(6.4)$ \\
\hline Other relatives & $90(25.1)$ \\
\hline $\begin{array}{l}\text { Occupation of fathers/male } \\
\text { guardians }\end{array}$ & \\
\hline Farming & $160(44.6)$ \\
\hline Trading & $33(9.2)$ \\
\hline${ }^{1}$ Artisans & $133(37.0)$ \\
\hline Unemployed & $4(1.1)$ \\
\hline Don't know & $29(8.1)$ \\
\hline Household size & \\
\hline $1-5$ & $185(51.5)$ \\
\hline $6-10$ & $160(44.6)$ \\
\hline$>10$ & $14(3.9)$ \\
\hline Children who have siblings & \\
\hline Yes & $341(95.0)$ \\
\hline No & $18(5.0)$ \\
\hline
\end{tabular}

${ }^{1}$ Artisans includes carpenters, masons, tailors etc

The results of the breakfast habits of the school children are presented in Table 2. A total of 307 (85.5\%) children had breakfast on the day of interview. Most of them $(87.6 \%)$ had their breakfast at home. About 97 of the children liked the breakfast served to them. 
Table 2 Breakfast habits of Ghanaian school children $(\mathrm{N}=359)$

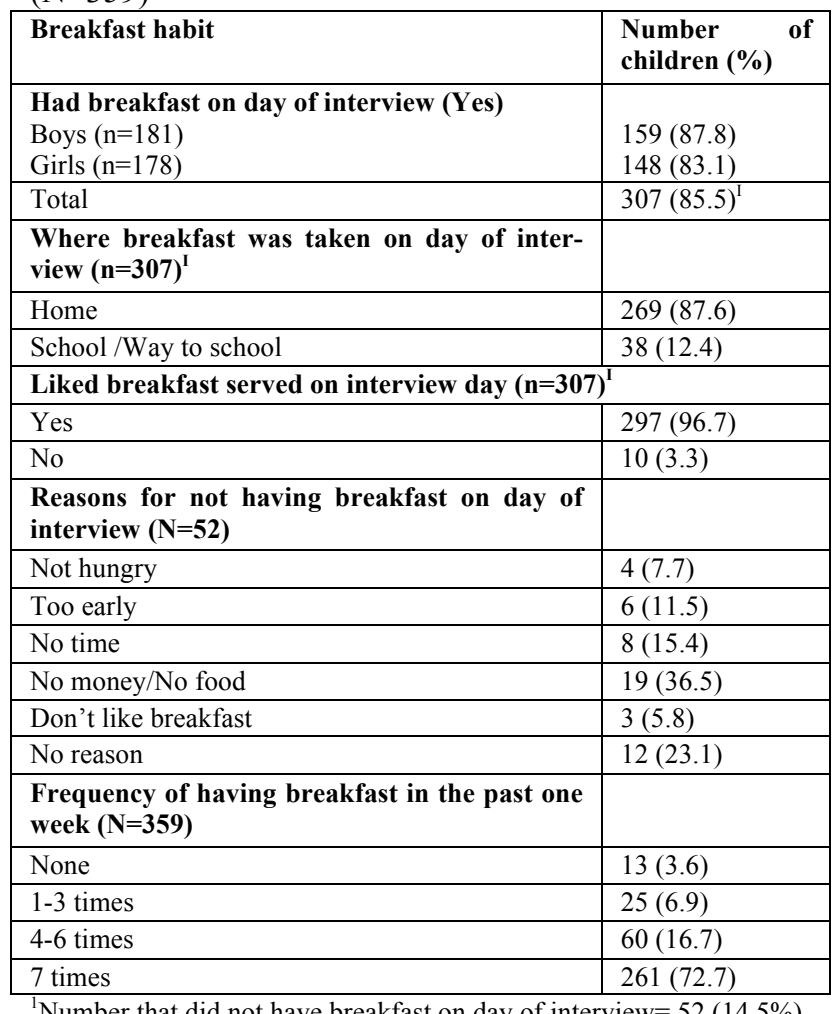

Of those who did not have breakfast $(14.5 \%)$, various reasons were given, the main reason being the lack of money or food for breakfast at home. Some of the children $(3.6 \%)$ did not have any breakfast throughout the past one week.

Based on whether breakfast was consumed or not on the day of interview, the energy and nutrient intakes of the two groups of children (breakfast-consumers verses non-consumers) were compared (Table 3). Generally those who had breakfast on the day of interview had significantly higher intakes of energy, and most nutrients, (except for protein, riboflavin and calcium) compared to those who did not have breakfast.

Breakfast meals were mainly cereal based foods which included banku (dumpling from fermented maize dough) which was normally consumed with pepper and fish, akasa or koko (porridge from fermented maize dough), hausa koko (porridge from fermented millet dough), rice and sometimes beverage from cocoa powder. The porridges were sweetened with sugar and were usually eaten with white bread (Table 4).

Table 3 Comparison of energy and nutrient intakes between children who had breakfast and children who skipped breakfast on the day of interview (Upper primary children only ( $\mathrm{N}=180)$

\begin{tabular}{|l|l|l|l|}
\hline Nutrient & $\begin{array}{l}\text { Had breakfast } \\
(\mathbf{N = 1 5 1 )} \\
(\text { Mean } \pm \text { SD) }\end{array}$ & $\begin{array}{l}\text { No breakfast } \\
\mathbf{( N = 2 9 )} \\
(\mathbf{M e a n} \pm \text { SD) }\end{array}$ & P-value \\
\hline Energy (kcal) & $2259 \pm 798$ & $1360 \pm 596$ & $0.039^{*}$ \\
\hline Protein $(\mathrm{g})$ & $56 \pm 22.2$ & $32.7 \pm 17.6$ & 0.060 \\
\hline Vitamin A (ug/RE) & $1534 \pm 13.4$ & $662 \pm 819$ & $0.001^{*}$ \\
\hline Thiamine (mg) & $0.91 \pm 0.45$ & $0.53 \pm 0.22$ & $0.010^{*}$ \\
\hline Riboflavin (mg) & $0.69 \pm 0.28$ & $0.41 \pm 0.22$ & 0.084 \\
\hline Vitamin C (mg) & $127 \pm 95.7$ & $58 \pm 42.0$ & $0.007^{*}$ \\
\hline Iron (mg) & $22.9 \pm 10.5$ & $13.9 \pm 7.4$ & $0.017^{*}$ \\
\hline Zinc (mg) & $9.9 \pm 4.3$ & $5.6 \pm 3.1$ & $0.034^{*}$ \\
\hline Calcium (mg) & $409 \pm 237$ & $237 \pm 187$ & 0.080 \\
\hline
\end{tabular}

*significantly different at P-value of $\leq 0.05$ t-test

The contribution of breakfast to the total daily energy and nutrient intake was determined (Table 5). The age categorizations used in Table 5 were based on age groupings used on Dietary Reference Intake recommendations (Estimated Average Requirements) ${ }^{16}$ for children.
The breakfast meal contributed to between $32 \%$ and $41.3 \%$ of the total daily energy and between $23.4 \%$ and $55.7 \%$ of the other nutrients. The percent contribution of breakfast meal to vitamin A intake ranged between $31.7 \%-55.7 \%$ (i.e. $361-846$ ug RE). Breakfast meal contributed between $35.5-51.5 \%$ of iron and 35.1$45.6 \%$ of zinc intakes for all age categories (Table 5). 
Table 4 Frequency of consumption of selected foods for breakfast in the past one week

\begin{tabular}{|c|c|c|c|c|c|c|}
\hline $\begin{array}{l}\text { Food group and } \\
\text { food item }\end{array}$ & $\begin{array}{l}\text { Not consumed } \\
\text { by } \\
\text { N }(\%) \\
\end{array}$ & $\begin{array}{l}\text { Consumed once } \\
\text { per week by } \\
\mathrm{N}(\%) \\
\end{array}$ & $\begin{array}{l}\text { Consumed } 2-4 x \\
\text { per week by } \\
\text { N }(\%) \\
\end{array}$ & $\begin{array}{l}\text { Consumed }>4 \\
\text { per week by } \\
\text { N }(\%) \\
\end{array}$ & $\begin{array}{l}\text { Food item not } \\
\text { known by } \\
\text { N (\%) } \\
\end{array}$ & $\begin{array}{l}\text { Consumed at least } \\
\text { once per week by } \\
\text { N (\%) }\end{array}$ \\
\hline \multicolumn{7}{|l|}{ Porridges } \\
\hline${ }^{1}$ Hausa koko & $125(70.2)$ & $32(18.0)$ & $15(8.4)$ & $4(2.2)$ & $2(1.1)$ & $51(28.6)$ \\
\hline${ }^{2}$ Akasa & $81(45.5)$ & $55(30.9)$ & $36(20.2)$ & $6(3.4)$ & $0(0.0)$ & $97(54.5)$ \\
\hline Tom brown & $141(79.2)$ & $23(12.9)$ & $11(6.2)$ & $3(1.7)$ & $0(0.0)$ & $37(20.8)$ \\
\hline${ }^{3}$ Oblayo & $117(65.7)$ & $40(22.5)$ & $20(11.2)$ & $1(0.6)$ & $0(0.0)$ & $61(34.3)$ \\
\hline${ }^{4}$ Ekuegbemi & $141(79.2)$ & $24(13.5)$ & $12(6.7)$ & $0(0.0)$ & $1(0.6)$ & $36(20.2)$ \\
\hline Rice porridge & $121(68.0)$ & $32(18.0)$ & $22(12.4)$ & $3(1.7)$ & $0(0.0)$ & $57(32.1)$ \\
\hline Oats & $140(78.7)$ & $16(9.0)$ & $11(6.2)$ & $0(0.0)$ & $11(6.2)$ & $27(15.2)$ \\
\hline \multicolumn{7}{|l|}{ Beverages } \\
\hline Cocoa & $112(62.9)$ & $41(23.0)$ & $21(11.8)$ & $4(2.2)$ & $0(0.0)$ & $66(37.0)$ \\
\hline Tea & $140(78.7)$ & $27(15.2)$ & $10(5.6)$ & $1(0.6)$ & $0(0.0)$ & $38(21.4)$ \\
\hline Coffee & $154(86.5)$ & $16(9.0)$ & $7(3.9)$ & $0 \quad(0.0)$ & $1(0.6)$ & $23(12.9)$ \\
\hline Milk & $112(62.9)$ & $42(23.6)$ & $21(11.8)$ & $3(1.7)$ & $0(0.0)$ & $66(36.9)$ \\
\hline Fruit juice & $140(78.7)$ & $17(9.6)$ & $17(9.6)$ & $4(2.2)$ & $0(0.0)$ & $38(21.4)$ \\
\hline Coke/fanta & $141(79.2)$ & $22(12.4)$ & $12(6.7)$ & $3(1.7)$ & $0(0.0)$ & $37(20.8)$ \\
\hline \multicolumn{7}{|l|}{ Breads } \\
\hline Bread & $74(41.6)$ & $55(30.9)$ & $37(20.8)$ & $12(6.7)$ & $0(0.0)$ & $104(58.4)$ \\
\hline${ }^{5}$ Bofrot & $138(77.5)$ & $26(14.6)$ & $11(6.2)$ & $3(1.7)$ & $0(0.0)$ & $40(22.5)$ \\
\hline${ }^{6} \mathrm{Kose} / \mathrm{akasa}$ & $146(82.0)$ & $18(10.1)$ & $13(7.3)$ & $1(0.6)$ & $0(0.0)$ & $32(18.0)$ \\
\hline Pie/chips & $132(74.2)$ & $24(13.5)$ & $19(10.7)$ & $3(1.7)$ & $0(0.0)$ & $46(25.9)$ \\
\hline Biscuits & $119(66.9)$ & $30(16.9)$ & $28(15.7)$ & $4(0.6)$ & $0(0.0)$ & $62(33.2)$ \\
\hline \multicolumn{7}{|c|}{ Main carbohydrate foods } \\
\hline Banku & $65(36.5)$ & $41(23.0)$ & $62(34.8)$ & $10(5.6)$ & $0(0.0)$ & $113(63.4)$ \\
\hline Kenkey & $96(53.9)$ & $41(23.0)$ & $32(18.0)$ & $9(5.1)$ & $0(0.0)$ & $82(46.1)$ \\
\hline Rice & $100(56.2)$ & $34(19.1)$ & $40(22.5)$ & $4(2.2)$ & $0(0.0)$ & $74(43.8)$ \\
\hline Gari and beans & $123(69.1)$ & $31(17.4)$ & $20(11.2)$ & $4(2.1)$ & $0(0.0)$ & $55(30.7)$ \\
\hline Plantain & $136(76.4)$ & $25(14.0)$ & $17(9.6)$ & $0(0.0)$ & $0(0.0)$ & $42(23.6)$ \\
\hline Yam & $125(70.2)$ & $32(18.0)$ & $20(11.2)$ & $1(0.6)$ & $0(0.0)$ & $53(29.8)$ \\
\hline Cocoyam & $129(72.5)$ & $29(16.3)$ & $17(9.6)$ & $3(1.7)$ & $0(0.0)$ & $49(27.6)$ \\
\hline Gari & $136(76.4)$ & $25(14.0)$ & $17(9.6)$ & $0(0.0)$ & $0(0.0)$ & $42(23.6)$ \\
\hline${ }^{7}$ Fufu & $114(80.9)$ & $20(11.2)$ & $13(7.3)$ & $1(0.6)$ & $0(0.0)$ & $34(19.1)$ \\
\hline${ }^{8}$ Kokonte & $166(93.3)$ & $7(3.9)$ & $5(2.8)$ & $0(0.0)$ & $0(0.0)$ & $12(6.7)$ \\
\hline Sweet potatoes & $153(86.0)$ & $16(9.0)$ & $9(5.1)$ & $0(0.0)$ & $0(0.0)$ & $25(14.1)$ \\
\hline${ }^{9}$ Abolo & $150(84.3)$ & $17(9.6)$ & $8(4.5)$ & $2(1.1)$ & $1(0.6)$ & $27(15.2)$ \\
\hline \multicolumn{7}{|l|}{ Protein foods } \\
\hline Fish & $61(34.3)$ & $47(26.4)$ & $46(25.8)$ & $24(13.5)$ & $0(0.0)$ & $117(65.7)$ \\
\hline Egg & $118(66.3)$ & $38(21.3)$ & $20(11.2)$ & $2(1.1)$ & $0(0.0)$ & $60(33.6)$ \\
\hline Chicken & $137(77.0)$ & $31(17.4)$ & $10(5.6)$ & $0(0.0)$ & $0(0.0)$ & $41(2.3)$ \\
\hline $\begin{array}{l}\text { Beef } \\
\text { Condiments }\end{array}$ & $158(88.8)$ & $10(5.6)$ & $10(5.6)$ & $0(0.0)$ & $0(0.0)$ & $20(11.2)$ \\
\hline Groundnut paste & $150(84.3)$ & $15(8.4)$ & $10(5.6)$ & $0(0.0)$ & $3(1.7)$ & $25(14.1)$ \\
\hline Cheese & $162(91.0)$ & $6(3.4)$ & $5(2.8)$ & $0(0.0)$ & $5(2.8)$ & $11(6.2)$ \\
\hline Condensed milk & $147(82.6)$ & $14(9.0)$ & $10(5.6)$ & $1(0.6)$ & $6(3.4)$ & $25(15.8)$ \\
\hline Margarine & $139(78.1)$ & $26(14.6)$ & $11(6.2)$ & $2(1.1)$ & $0(0.0)$ & $39(21.9)$ \\
\hline \multicolumn{7}{|l|}{ Fruits } \\
\hline Mango & $153(86.0)$ & $16(9.0)$ & $8(4.5)$ & $1(0.6)$ & $0(0.0)$ & $25(14.1)$ \\
\hline Orange & $125(70.2)$ & $27(15.2)$ & $24(13.5)$ & $2(1.1)$ & $0(0.0)$ & $53(29.8)$ \\
\hline Pineapple & $154(86.5)$ & $13(7.3)$ & $11(6.2)$ & $0(0.0)$ & $0(0.0)$ & $24(13.5)$ \\
\hline Watermelon & $158(88.8)$ & $14(7.9)$ & $6(6.2)$ & $0(0.0)$ & $0(0.0)$ & $20(14.1)$ \\
\hline Banana & $128(71.9)$ & $22(12.4)$ & $27(15.2)$ & $1(0.6)$ & $0(0.0)$ & $50(28.2)$ \\
\hline Pawpaw & $150(84.3)$ & $14(7.9)$ & $13(7.3)$ & $1(0.6)$ & $0(0.0)$ & $28(15.8)$ \\
\hline Apple & $157(88.2)$ & $6(3.4)$ & $13(7.3)$ & $2(1.1)$ & $0(0.0)$ & $21(11.8)$ \\
\hline Sugar cane & $156(87.6)$ & $15(8.4)$ & $7(3.9)$ & $0(0.0)$ & $0(0.0)$ & $22(12.3)$ \\
\hline
\end{tabular}


Table 5 Percent contribution of breakfast meal to the total daily nutrient intake among upper primary school children who took breakfast $(\mathrm{N}=151)$

\begin{tabular}{|c|c|c|c|c|c|c|c|c|c|c|c|c|}
\hline Age in years & Sex & $\begin{array}{l}\text { Energy } \\
\text { Kcal }\end{array}$ & $\begin{array}{l}\text { Prtein } \\
\text { (g) }\end{array}$ & Fat (g) & $\begin{array}{l}\text { CHO } \\
\text { (g) }\end{array}$ & $\begin{array}{l}\text { VIT.A } \\
\text { (ug RE) }\end{array}$ & $\begin{array}{l}\text { Thiamin } \\
\text { (g) }\end{array}$ & $\begin{array}{l}\text { Riboflavin } \\
\text { (mg) }\end{array}$ & $\begin{array}{l}\text { VIT. C } \\
(\mathrm{mg})\end{array}$ & $\begin{array}{l}\text { Iron } \\
\text { (mg) }\end{array}$ & $\begin{array}{l}\text { Zinc } \\
(\mathrm{mg})\end{array}$ & $\begin{array}{l}\text { Calcium } \\
\text { (mg) }\end{array}$ \\
\hline $9-13 \mathrm{Y}$ & $\begin{array}{l}\text { Male } \\
\quad \mathrm{N}=57\end{array}$ & ${ }^{\mathrm{BF}} 715$ & 20.4 & 17.5 & 122 & 559 & 0.28 & 0.20 & 30.5 & 7.8 & 3.3 & 119 \\
\hline 24 -hour ${ }^{1}$ & & 2231 & 52.5 & 48.8 & 410 & 1501 & 0.85 & 0.64 & 126 & 22.0 & 9.4 & 359 \\
\hline$\% \mathrm{BF}^{2}$ & & 32.0 & 38.1 & 35.9 & 29.8 & 37.2 & 32.9 & 31.3 & 24.2 & 35.5 & 35.1 & 33.1 \\
\hline $9-13 \mathrm{Y}$ & $\begin{array}{c}\text { Female } \\
\mathrm{N}=53\end{array}$ & ${ }^{\mathrm{BF}} 756$ & 20.0 & 17.3 & 134 & 510 & 0.35 & 0.24 & 30 & 9.0 & 3.6 & 161 \\
\hline 24 -hour ${ }^{1}$ & & 1943 & 50.6 & 49.0 & 346.7 & 1342 & 0.79 & 0.63 & 104 & 20.7 & 8.9 & 393 \\
\hline$\% \mathrm{BF}^{2}$ & & 38.9 & 39.5 & 35.3 & 38.7 & 38.0 & 44.3 & 38.1 & 28.8 & 43.5 & 40.4 & 40.9 \\
\hline 14-19 Y & $\begin{array}{l}\text { Male } \\
\quad \mathrm{N}=22\end{array}$ & ${ }^{\mathrm{BF}} 824$ & 23.2 & 21.7 & 137 & 846 & 0.32 & 0.25 & 30.9 & 9.4 & 4.2 & 173 \\
\hline 24-hour ${ }^{1}$ & & 2237 & 56.4 & 52.1 & 402 & 1520 & 0.94 & 0.71 & 132 & 22.6 & 9.8 & 413.2 \\
\hline$\% \mathrm{BF}^{2}$ & & 36.8 & 41.1 & 41.7 & 34.1 & 55.7 & 34.0 & 35.2 & 23.4 & 41.6 & 42.9 & 41.9 \\
\hline $14-19 \mathrm{Y}$ & $\begin{array}{l}\text { Female } \\
\mathrm{N}=19\end{array}$ & ${ }^{\mathrm{BF}} 895$ & 21.6 & 14.6 & 170 & 361 & 0.44 & 0.25 & 32.7 & 10.6 & 4.1 & 147 \\
\hline 24-hour ${ }^{1}$ & & 2169 & 52.3 & 41.3 & 410 & 1138 & 0.93 & 0.66 & 103.8 & 20.6 & 9.0 & 377 \\
\hline$\% \mathrm{BF}^{2}$ & & 41.3 & 41.3 & 35.4 & 41.5 & 31.7 & 47.3 & 37.9 & 31.5 & 51.5 & 45.6 & 38.9 \\
\hline
\end{tabular}

${ }^{\mathrm{BF}}$ Figures on that row represent mean nutrient intake at breakfast, ${ }^{1} 24$-hour dietary recall nutrient consumption on the day of interview, ${ }^{2}$ percentage contribution of breakfast to total daily nutrient intake

\section{DISCUSSION}

This study shows that the breakfast meal contributes significantly to the total energy and nutrient intakes of Ghanaian school children. Majority $(72.7 \%)$ of the children in the study consume breakfast regularly. In the USA between $69-80 \%$ of children were reported to have breakfast. ${ }^{2}$ Another study among children in Netherlands reported a prevalence of $95 \%$ breakfast consumption. ${ }^{17} \mathrm{~A}$ review of studies on breakfast habits reported that breakfast skipping among children was between $10-30 \%$ for European children. American children were the worst breakfast skippers. ${ }^{18}$ Consistent with other studies ${ }^{5,19}$, more Ghanaian girls $(16.9 \%)$ than boys (12.2\%) in our study skipped breakfast.

The probable explanation is that girls especially adolescents are more concerned about their weight and therefore more likely to skip their breakfast with the intention of keeping their weight under control. However, some studies have shown that skipping breakfast may not result in weight loss. ${ }^{20,21}$ The reasons being that skipping breakfast resulted in poor eating habits such as inappropriate snacking on high fat and high sugary foods which could lead to excess energy consumption and subsequently being overweight.

As was expected, more of the children had their breakfast at home (87.6\%) than at school or on the way to school (12.4\%). Children are more likely to eat street foods if they are not fed at home. However, among those who skipped breakfast, lack of time $(15.4 \%)$ on the part of parents and children was one of the reasons children not having breakfast. Similar reasons were reported by other studies. ${ }^{22,} 23$ Among Spanish children, $95 \%$ reported having breakfast at home, indicating an effort on the part of parents to ensure that their children took breakfast.

In our study, children who skipped breakfast did so because there was no food or money at home. Other studies have attributed low socioeconomic status and poor education of parents as some reasons why children skip breakfast. ${ }^{15,24}$ It should also be noted that this study was carried out between February and March which is considered a lean season in the study area. Since lean seasons are usually characterized by very high prices in food commodities, it is likely this would affect the quantity and the nutritional quality of foods consumed by the children and not necessarily the frequency of consumption. This may explain the high frequency of consuming breakfast among the children even in the lean season. Notwithstanding, the number of children consuming breakfast in the mornings is comparable to other studies elsewhere. ${ }^{2}$

In this study, without breakfast, many of the children would not have met their daily nutrient requirements, due to the difficulty to compensate for energy and nutrients lost in the morning when conscious effort is not made to replace nutrients lost. ${ }^{24}$ Some studies also found that breakfast consumers had significantly higher intakes of micronutrients like vitamin $\mathrm{A}$, thiamine, vitamin $\mathrm{C}$, iron, calcium and zinc. ${ }^{8,25,26}$

Among our Ghanaian children breakfast meals did not contribute significantly to calcium intake. This is not surprising as milk and milk products are rarely con- 
sumed as part of the breakfast meal in the rural setting in Ghana. The relatively high cost of milk and milk products in Ghana discourage consumption, even among young children.

In conclusion, consumption of breakfast is a common practice among the Ghanaian schoolchildren studied. Children who had breakfast generally had significantly higher nutrient intakes than children who did not. Encouraging breakfast consumption among school children is a way to ensure that they meet their daily nutrient and energy intakes. Parents and Caregivers should be educated on the benefits of breakfast for children. This should include what makes a nutritious breakfast to ensure that the children are not only fed breakfast but also one that enhances their nutritional status.

\section{REFERENCES}

1. Giovannini M, Verduci E, Scaglion S, Salvatici E, Bonza M, Riva, E. C Agostoni Breakfast: a Good Habit, not a Repetitive Custom. J Int Med Res 2008; 36(4): 613-624(12)

2. Deshmukh-Taskar PR, Nicklas TA, O'Neil CE, Keast DR, Radcliffe JD, S Cho The relationship of breakfast skipping and type of breakfast consumption with nutrient intake and weight status in children and adolescents: the National Health and Nutrition Examination Survey 1999-2006. J Am Diet Assoc. 2010; 110(6):869

3. Chitra U and R Reddy The role of breakfast in nutrient intake of schoolchildren. Public Health Nutr 2007;10(1):55-58

4. Nicklas TA, Bao W, Webber LS, and GS Berenson Breakfast consumption affects adequacy of total daily intake in children. $J$ Am Diet Assoc 1993;8: 886-891

5. Nicklas TA, Reger $\mathrm{C}$ Myers $\mathrm{L}$ and $\mathrm{C}$ O'Neil Breakfast Consumption With and Without Vitamin-mineral Supplement Use Favourably Impacts Daily Nutrient Intake of Ninth-grade Students. $J$ Adolesc Health 2000; 27(5):314-21

6. Dwyer JT, Evans M, Stone EJ, Feldman HA, Lytle L, Hoelscher D, Johnson C, Zive M, and M Yang Child and Adolescent Trial for Cardiovascular Health (CATCH) Cooperative Research Group Adolescents' Eating Patterns Influence Their Nutrient Intakes. J Am Diet Assoc 2001;101(7):798802

7. Stockman NKA, Schenkel TC, Brown JN, and AM Duncan Comparison of energy and nutrient intakes among meals and snacks of adolescent males. Preventive Medicine 2005; 41:203-210

8. Ruxton $\mathrm{CH}$ and TR Kirk Breakfast: a review of associations with measures of dietary intake, physiology and biochemistry. Br J of Nutr 1997 18:2:199-213
9. Barton BA, Eldridge AL, Thompson D, Affenito SG, Striegel-Moore RH, Franko DL, Albertson AM, and SJ Crockett The Relationship of Breakfast and Cereal Consumption to Nutrient Intake and Body Mass Index: the National Heart, Lung, and Blood Institute Growth and Health Study. $J$ Am Diet Assoc. 2005; 105(9):1383-9.

10. Widenhorm-Muller K, Hille K, Klenk J and U Weiland Influence of having breakfast on cognitive performance and mood on 13-20 year old high students: results of a crossover trial. Pediatrics 2008; 22(2)

11. Dykman R, and RT Pivik Effects of a school breakfast on mental arithmetic task performance. Pediatric Academic Society 2002; 51:453

12. Fernald L Ani CC and S Grantham-Mcgregor Does School breakfast benefit children's educational performance? African Health 1997;19(6):19-20

13. Mahoney CR, Taylor H A, Kanarek R B, and P Samuel Effect of breakfast composition on cognitive processes in elementary school children. Physiology \& Behavior 2005; 85(5) 635-645

14. Wesnes KA, Pincook C, Richardson D, Helm G, and $\mathrm{S}$ Hails Breakfast reduces declines in attention and memory over the morning in schoolchildren. Appetite 2003;41(3)329-331

15. Eyeson K, Ankrah EK, Sundararajan AR, Karinpaa $\mathrm{A}$, and JM Rudzka Composition of foods commonly used in Ghana. Accra, Ghana: Food Research Institute. Council for Scientific and Industrial Research, 1975

16. Institute of Medicine (IOM), Dietary Reference Intakes (DRIs): Estimated Average Requirements Food and Nutrition Board, National Academies. [Online]

Available:

http://www.iom.edu/Activities/Nutrition/Summary DRIs/ /media/Files/Activity\%20Files/Nutrition/D RIs/5_Summary\%20Table\%20Tables\%201-4.pdf (15 ${ }^{\text {th }}$ May, 2013)

17. Brugman E, Meulmeester JF, Spee-van der wekke A, and SP Verloove-Vanhorick Breakfast-skipping in children and young adolescents in The Netherlands. Eur J Public Health 1998;8:4

18 Rampersaud GC, Pereira MA, Girard BL, Adams J. and JD Metzl, Breakfast Habits, Nutritional Status, Body Weight, and Academic Performance in Children and Adolescents $J$ Am Diet Assoc 2005; 105(5)743-760

19. Ortega R. M., Ana Maria Requejo, Ana M. LopezSobaler, Andre P, Quintas EM, Navia B, Izquierdo $\mathrm{M}$, and $\mathrm{T}$ Rivas The Importance of Breakfast in Meeting Daily Recommended Calcium Intake in a Group of Schoolchildren, $J$ Am Coll Nutr 1998;17(1):19-24 
20. Berkey CS, Rockett HRH, Gillman MW, Field AE, and GA Colditz Longitudinal study of skipping breakfast and weight change in adolescents. Int J Obes Relat Metab Disord 2003;27: 1258-66

21. Siega-Riz A-M, Popkin B, and T Carson Trends in breakfast consumption for children in the United States from 1965-1991. Am J of Clin Nutr 1998;67:748S-56S

22. Cheng TSY, Tse LA, Tak-Sun I and YS Griffiths Children's perceptions of parental attitude affecting breakfast skipping in primary sixth-grade students, J Sch Health 2008;78(4)203-208

23. Singleton N and DS Rhoads Meal and snack patterns of students. J Sch Health 1982; 52:529-534

24. O'Dea JA and P Caputi Association between socioeconomic status, weight, age and gender, and the body image and weight control practices of 6to 19-year-old children and adolescents, Health Educ Res. 2001;16:521-532.
25. Kruger HS, Dhansay MA, Labadarios D, Kotiah M, L, Kullman The importance of breakfast in meeting nutritional requirements of South African children - A review. South African Journal of Clinical Nutrition 2002;15 (1)5-12

26. Gleason P and C Suitor Children's Diets in the Mid-1990s: Dietary Intake and Its Relationship with School Meal Participation. U.S. Department of Agriculture, Food and Nutrition Service, Office of Analysis, Nutrition and Evaluation, CN01-CD1, Alexandria 2001

27. Affenito S G, Thompson DR, Barton BA, Franko DL, Daniels SR, Obarzanek E, Schreiber GB, RH Striegel-Moore Breakfast Consumption by African-American and White Adolescent Girls Correlates Positively with Calcium and Fiber Intake and Negatively with Body Mass Index. J Am Diet Assoc 2005;105(6) 938-945 